\title{
Trade Structure and Trade Potential in East Asia*
}

\author{
Sang-yirl Nam**
}

\begin{abstract}
World trade has been increasing rapidly and much faster than world output. This study analyzes the trade structures of major dynamic East Asian countries as well as regional subgroups such as ASEAN members and Northeast Asian countries. Emphasis will be on the complementarities that would enhance integration among them through international trade. In addition, potential trade levels for each combination of East Asian countries are estimated by applying the gravity model of trade to the trade flows of 21 APEC members, as a reference group. It is estimated to have significant potentiality by regional subgroup, ASEAN or Northeast Asia, and not between the two regional subgroups. However, the potential integration between East Asian countries in different regional subgroups is more significant by considering complementarities in trade compared with the results from the basic gravity model. To enhance economic cooperation between East Asian countries, expanding relationships such as inter-industry trade in natural resources trade and industrial goods between the regional subgroups needs to occur. They should also utilize complementary relationships from intra-industry trade in industrial goods such as electric and electronic equipment, related parts and accessories. And they should focus on the implementation of trade facilitation measures based on global standards.
\end{abstract}

Keywords: Trade complementarity, East Asia, Gravity Model, Trade Structure, Potential Trade

\section{INTRODUCTION}

World trade has increased rapidly and much faster than world output. Proliferation of regional trade agreements as well as multilateral trade liberalization was believed to have significantly contributed to the changes. One of the most dynamic performances can be found in East Asian countries. For example, developing East

\footnotetext{
"This paper focuses on East Asian countries utilizing and updating the analysis in Nam (2003). Especially, it differentiates trade flows by the directions between two countries. For example, trade flows from country $j$ to country $k$ and those from country $k$ to $j$ are entered in the analysis separately and independently.

" Research Fellow, Korea Institute for International Economic Policy (KIEP), 300-4 Yomgok-Dong, Seocho-Gu, Seoul 137-747, Korea e-mail: synam@kiep.go.kr
} 
Asian countries recorded 11 percent of annual average growth in their exports during 1990-2000 compared with 6 percent of that in global export during the same period. However, no significant proliferation of institutional economic integration among East Asian countries can be observed compared with two other major regions, such as Europe and North America, in world trade. The purpose of this study is to analyze the trade structures of major East Asian countries as well as regional subgroups such as ASEAN members and Northeast Asian countries since the establishment of APEC in 1989. Emphasis will be on the complementarities that would enhance integration among them through international trade.' By using the index of trade conformity (ITC), the extent of complementarity in the aggregate trade structure between East Asian countries will be evaluated. Some commodities that make relatively large contributions to the ITC, and hence could potentially increase trade between East Asian countries, will also be identified. In addition, potential trade levels for each combination of East Asian countries are estimated by applying the gravity model of trade to the trade flows of 21 APEC members, as a reference group, including ITC as one of the explanatory variables. The potentiality will be compared with their actual trade performances. Based on the results from the analysis, some common sectors or ways to enhance the integration of East Asian countries as a whole through international trade and means to enlarge mutual benefits among these countries will be examined.

Table 1. World Output and World Trade Growth

(percent)

\begin{tabular}{l||c|c}
\hline \multicolumn{1}{c||}{} & \multicolumn{2}{c}{ Ten-Year Averages } \\
\cline { 2 - 3 } & $1984-1993$ & $1994-2003$ \\
\hline \hline World Output (Real GDP) & 3.3 & 3.5 \\
\hline World Trade Volume & & 6.5 \\
\hline$\quad$ Trade in Goods and Services & 5.6 & 6.7 \\
\hline$\quad$ Trade in Goods & 5.7 & \\
\hline
\end{tabular}

Source : IMF (2003), World Economic Outlook.

Table 2. Growth in the Value of Merchandise Trade by Region, 1990-2002

\begin{tabular}{l||c|c|c|c|c|c}
\hline \multicolumn{1}{c||}{} & \multicolumn{3}{c|}{ Exports } & \multicolumn{3}{c}{ Imports } \\
\cline { 2 - 7 } & $1990-2000$ & 2001 & 2002 & $1990-2000$ & 2001 & 2002 \\
\hline \hline World & 6 & -4 & 4 & 6 & -4 & 3 \\
\hline North America & 7 & -7 & -4 & 9 & -6 & 2 \\
\hline Western Europe & 4 & 0 & 5 & 4 & -2 & 4 \\
\hline Asia & 8 & -9 & 8 & 8 & -7 & 6 \\
\hline \multicolumn{1}{c}{ Developing Asia } & 11 & -7 & 10 & 9 & -7 & 9 \\
\hline
\end{tabular}

Source : WTO (2003), World Trade Report 2003.

\footnotetext{
'In this paper, East Asian countries include seven ASEAN members (Brunei, Indonesia, Malaysia, the Philippines, Singapore, Thailand and Vietnam) and five Northeast Asian economies (China, Hong Kong, Japan, Korea and Taiwan). Even though Hong Kong is officially called 'Hong Kong, China' and is not a country, we will use the term 'East Asian countries' for convenience when we refer to them collectively.
} 
The remaining part of this paper consists of the following contents. Overall trade structure and trends in East Asian countries are examined in part 2. Complementarity in East Asian trade is analyzed in part 3, by utilizing the ITC that measures structural similarity between one country's exports and another country's imports. In part 4, trade potential between East Asian countries is estimated with the gravity model of international trade taking into account complementarity in trade. In addition, some approaches for attaining the estimated trade potential will be identified. Part 5 then summarizes and gives some brief implications.

\section{TRADE STRUCTURE IN EAST ASIA}

\subsection{East Asian Countries' Share in World Trade}

The shares of East Asian countries in world merchandise imports and exports have increased from 18.7 percent and 21.8 percent in 1989 to 21.8 percent and 25.3 percent in 2001 , respectively. Overall, their share in world exports turned out to be significantly larger than that in world imports. By individual country, Japan (5.5 percent and 6.6 percent), China (4.1 percent and 5.2 percent), Hong Kong ( 3.1 percent and 2.8 percent), Korea (2.2 percent and 2.5 percent), Taiwan (1.6 percent and 2.0 percent), Singapore (1.8 percent and 2.0 percent), and Malaysia (1.2 percent and 1.4 percent) explain relatively large shares of world imports and exports in 2001, respectively. Though Northeast Asian countries explain significantly larger shares (16.5 percent and 19.0 percent in 2001) of world imports and exports than ASEAN members (5.3 percent and 6.3 percent), the shares of the latter have increased much faster since 1989 than those of the former. In Northeast Asia, a large increase in the share from China has been almost offset by a huge decrease in that from Japan since 1989. In ASEAN, every member economy except Brunei experienced an increase in its share of world trade between 1989 and 2001. The increases in their shares of world exports have been more significant than those of world imports, especially in Malaysia, Philippines, Vietnam, Thailand and Indonesia. Most of these countries had a relatively larger share of world exports than world imports in 2001, but exceptions can be observed in Hong Kong and Vietnam. 
Table 3. East Asian Countries' Share in World Merchandise Trade

\begin{tabular}{l||c|c|c|c|c|c}
\multicolumn{1}{c||}{} & \multicolumn{3}{c}{ Imports } & \multicolumn{3}{c}{ Exports } \\
\cline { 2 - 7 } & 1989 & 1995 & 2001 & 1989 & 1995 & 2001 \\
\hline \hline World Trade & $3,110,750$ & $5,139,010$ & $6,572,500$ & $2,985,650$ & $5,078,240$ & $6,247,960$ \\
\hline East Asia & 18.73 & 24.44 & 21.76 & 21.82 & 26.18 & 25.30 \\
\hline ASEAN & $\mathbf{4 . 1 5}$ & $\mathbf{6 . 9 3}$ & $\mathbf{5 . 2 5}$ & $\mathbf{4 . 1 5}$ & $\mathbf{6 . 3 2}$ & $\mathbf{6 . 3 2}$ \\
\hline Brunei & 0.03 & 0.06 & 0.02 & 0.06 & 0.07 & 0.05 \\
\hline Indonesia & 0.53 & 0.79 & 0.56 & 0.73 & 0.89 & 1.06 \\
\hline Malaysia & 0.73 & 1.51 & 1.15 & 0.84 & 1.45 & 1.43 \\
\hline Philippines & 0.36 & 0.55 & 0.55 & 0.26 & 0.34 & 0.56 \\
\hline Singapore & 1.60 & 2.42 & 1.77 & 1.50 & 2.33 & 1.95 \\
\hline Thailand & 0.82 & 1.43 & 0.94 & 0.68 & 1.13 & 1.04 \\
\hline Vietnam & 0.10 & 0.16 & 0.26 & 0.08 & 0.11 & 0.23 \\
\hline Northeast Asia & $\mathbf{1 4 . 5 8}$ & $\mathbf{1 7 . 5 1}$ & $\mathbf{1 6 . 5 1}$ & $\mathbf{1 7 . 6 7}$ & $\mathbf{1 9 . 8 6}$ & $\mathbf{1 8 . 9 8}$ \\
\hline China & 1.90 & 2.57 & 4.06 & 1.77 & 2.93 & 5.15 \\
\hline Hong Kong & 2.32 & 3.75 & 3.11 & 2.45 & 3.42 & 2.83 \\
\hline Japan & 6.74 & 6.54 & 5.53 & 9.20 & 8.72 & 6.58 \\
\hline Korea & 1.94 & 2.63 & 2.18 & 2.03 & 2.59 & 2.45 \\
\hline Taiwan & 1.68 & 2.01 & 1.63 & 2.22 & 2.20 & 1.97 \\
\hline Sourc: Cala on & & & & & \\
\hline
\end{tabular}

Source : Calculated from the data in IMF (2003), Direction of Trade Statistics, CD-ROM and Taiwan Ministry of Finance (2002), Monthly Statistics of Exports and Imports Taiwan Area September 2002, October.

\subsection{Trade Structure by Regional Subgroup}

Trade relationships between East Asian countries by regional subgroup are examined, especially between ASEAN members and Northeast Asian countries for 1989, 1995 and 2001, respectively. Trade relationship can be denoted by a country's exports to or imports from other East Asian countries. We examined trade relationship both in terms of imports by origin and exports by destination.

According to the IMF (2003) and the Taiwan Ministry of Finance (2002), the share of East Asian countries' imports from within East Asian countries is estimated to have significantly increased from 43.2 percent in 1989 to 52.8 percent in 2001 . These import shares are much greater than their shares of global imports (18.7 percent in 1989, and 21.8 percent in 2001). These two indicators denote that East Asian countries are more closely related to each other than to the rest of the world in terms of their imports. They are also becoming more and more integrated with each other.

A similar analysis can be applied to East Asian countries' exports. The share of exports going from East Asian countries to other East Asian countries is also estimated to have significantly increased from 38.2 percent in 1989 to 46.5 percent in 2001. These export shares are much greater than their shares in world exports $(21.8$ percent in 1989 and 25.3 percent in 2001, respectively). Again, these two indicators show that East Asian countries are much more closely related to each other than to the rest of the world as a whole in terms of their exports. They are also increasingly integrated with each other in general. 
One of the most important characteristics of intra-regional trade in East Asia is more and more integration by regional subgroup, ASEAN or Northeast Asia, and not so much the progress between the two regional subgroups in terms of trade share. Even though integration through international trade has significantly progressed in East Asia (i.e., increased intra-regional trade share) since 1989, most of the progress was attributable to the significant development of integration by regional subgroup, ASEAN and Northeast Asia, itself. Trade shares between the two regional subgroups have almost been stagnant. The only exception is Northeast Asian countries' import share from ASEAN members, which increased somewhat from 9.4 percent in 1989 to 12.3 percent in 2001 . This phenomenon seems to be important for the more preferable integration of East Asia as a whole.

Overall, East Asian countries have a significantly larger share of their imports from themselves (intra-regional imports) than that of their exports to themselves (intra-regional exports), i.e., 52.8 percent and 46.5 percent in 2001, respectively. In addition, ASEAN members have a relatively larger share of imports and exports within East Asia (56.5 percent and 53.2 percent in 2001, respectively) than Northeast Asian countries (51.6 percent and 44.2 percent in 2001, respectively). Especially, ASEAN members have a significantly larger share of imports and exports with Northeast Asian countries (35.0 percent and 31.7 percent in 2001, respectively) than Northeast Asian countries' share of imports and exports with ASEAN members (12.3 percent and 9.7 percent in 2001, respectively). Northeast Asian countries have a significantly larger share of imports and exports within themselves (39.3 percent and 34.6 percent in 2001, respectively) than ASEAN members' share of imports and exports within ASEAN (21.5 percent and 21.5 percent in 2001, respectively).

Table 4. East Asian Countries' Intra-Regional Trade Share by Regional Subgroup

\begin{tabular}{|c|c|c|c|c|c|c|c|}
\hline \multirow[t]{2}{*}{ Origin } & \multirow[t]{2}{*}{ Destination } & \multicolumn{3}{|c|}{$\begin{array}{l}\text { Origin's Share in Aggregate } \\
\text { Imports of Destination }\end{array}$} & \multicolumn{3}{|c|}{$\begin{array}{l}\text { Destination's Share in } \\
\text { Aggregate Exports of Origin }\end{array}$} \\
\hline & & 1989 & 1995 & 2001 & 1989 & 1995 & 2001 \\
\hline \multirow[t]{3}{*}{ E. Asia } & E. Asia & 43.2 & 50.2 & 52.8 & 38.2 & 48.6 & 46.5 \\
\hline & ASEAN & 50.3 & 55.8 & 56.5 & 10.0 & 15.7 & 12.6 \\
\hline & NE. Asia & 41.2 & 48.0 & 51.6 & 28.2 & 32.9 & 33.9 \\
\hline \multirow[t]{3}{*}{ ASEAN } & E. Asia & 10.5 & 12.8 & 14.5 & 48.8 & 53.5 & 53.2 \\
\hline & ASEAN & 14.5 & 17.6 & 21.5 & 17.6 & 23.8 & 21.5 \\
\hline & NE. Asia & 9.4 & 10.9 & 12.3 & 31.1 & 29.7 & 31.7 \\
\hline \multirow[t]{3}{*}{ NE. Asia } & E. Asia & 32.7 & 37.5 & 38.3 & 35.8 & 47.0 & 44.2 \\
\hline & ASEAN & 35.8 & 38.2 & 35.0 & 8.2 & 13.1 & 9.7 \\
\hline & NE. Asia & 31.8 & 37.2 & 39.3 & 27.5 & 33.9 & 34.6 \\
\hline
\end{tabular}

Note : E. Asia includes both ASEAN members and NE. Asia. ASEAN means its seven member countries. NE. Asia denotes China, Hong Kong, Japan, Korea and Taiwan.

Sources : Calculated from the data in IMF (2003), Direction of Trade Statistics, CD-ROM and Taiwan Ministry of Finance (2002), Monthly Statistics of Exports and Imports Taiwan Area September 2002, October. 


\subsection{Intra-East Asia Trade Structure by Country}

Trade relationships between East Asian countries can be summarized as a trade matrix, i.e., a country's imports or exports by each of the remaining countries in East Asia. Since a country's exports by country are the corresponding countries' imports, it is expected that the aggregate trade structure, or more specifically the trade matrix, of East Asian countries in a given year can be constructed in a single table. However, since export data is denoted in terms of Free on Board (FOB) and imports in terms of Cost, Insurance and Freight (CIF) in general, import data is expected to be somewhat greater than the corresponding export data for the same merchandise flows. In practice, some discrepancies cannot be explained only by the differences between CIF and FOB. ${ }^{2}$ To deal with this problem, we have constructed two trade matrices of East Asian countries in 2001 - one in terms of import share by origin and the other in terms of export share by destination as Table 5 indicates.

Overall, ASEAN members had a relatively large import share from Northeast Asian countries such as Japan, Korea and China followed by other ASEAN members such as Singapore and Malaysia. Northeast Asian countries, however, had a relatively large import share from other Northeast Asian countries, especially Japan and China but a relatively small import share from ASEAN members. Intra-East Asia regional import shares appeared relatively large in Hong Kong ( 82.7 percent) and most of the ASEAN members such as Brunei (74.6 percent), Vietnam (73.0 percent), Indonesia (61.7 percent) and Malaysia (58.4 percent) but relatively small in most of the Northeast Asian countries such as Japan (41.0 percent), Korea (42.0 percent) and China ( 47.0 percent in 2001).

In exports, ASEAN members had a relatively large export share to Northeast Asian countries, especially Japan, and Singapore. Northeast Asian countries, however, had a relatively large export share to other Northeast Asian countries, especially Japan, China and Hong Kong but a relatively small export share to ASEAN members. Intra-East Asia regional export share was recorded as relatively large by most of the ASEAN members such as Brunei (79.5 percent), Indonesia (56.3 percent) and Malaysia (55.1 percent) but relatively small in most of the Northeast Asian countries such as Japan (39.1 percent), Korea (43.7 percent) and China (44.7 percent in 2001), followed by Vietnam (45.0 percent) and Thailand (47.5 percent).

The Intra-East Asia regional import share increased in most of the East Asian countries between 1989 and 2001, especially in Vietnam (from 9.2 percent to 73.0 percent), Brunei (from 61.2 percent to 74.6 percent), Indonesia (from 47.1 percent to 61.7 percent), Japan (from 29.3 percent to 41.0 percent), Taiwan (from 43.4 percent to 52.5 percent), and Hong Kong (from 73.4 percent to 82.7 percent). The Intra-East Asia regional export share also increased in most of the East Asian countries between 1989 and 2001, especially in Vietnam (from 20.9 percent to 45.0 percent), Taiwan (from 34.3 percent to 50.7 percent), the Philippines (from 37.1 percent to 51.7 percent), Japan (from 28.6 percent to 39.1 percent), Singapore (from 43.2 percent to 53.9 percent), and Thailand

\footnotetext{
${ }^{2}$ For example, exports from Hong Kong to China are reported as $\$ 65.99$ billion for 2001 , but imports to China from Hong Kong as $\$ 38.03$ billion for the same year.
} 
(from 38.9 percent to 47.5 percent). Therefore, most East Asian Countries are increasingly integrated with each other both in terms of imports and exports.

The Intra-East Asia regional trade relationship by individual country in 2001 can be found in the trade matrices in terms of import share (column sum) or export share (row sum). For example, Brunei imported 74.6 percent of merchandise from East Asian countries and exported 79.5 percent of merchandise to East Asian countries in 2001. Brunei, in particular, had relatively large import shares with other ASEAN members such as Singapore (34.0 percent) and Malaysia (23.3 percent), and with East Asian countries such as Japan (4.3 percent) and Hong Kong (4.0 percent) in 2001. In contrast, Brunei had significantly large export shares with Northeast Asian countries such as Japan (47.1 percent) and Korea (12.3 percent) followed by other ASEAN members such as Thailand (10.6 percent) and Singapore (5.0 percent) in the same year.

Table 5. Trade Matrix of East Asian Countries in 2001

(a) Import Share by Origin Country

(percent)

\begin{tabular}{|c|c|c|c|c|c|c|c|c|c|c|c|c|}
\hline Org.IDest. & BRU & IND & MAL & PHL & SGP & THL & VET & CHI & HKC & JAP & KOR & CTP \\
\hline & & & & & & & & & & & & \\
\hline & 1.95 & & & & 0.00 & 2.20 & & 1.70 & & & 3.12 & 2.35 \\
\hline & 23.32 & & & 3.25 & 17.32 & 4.96 & & 1.97 & 2.43 & & 2.87 & 3.93 \\
\hline & 0.39 & 0.37 & & NA & 2.20 & 1.82 & 0.50 & 0.69 & 0.99 & & 1.27 & \\
\hline & 33.98 & 10.19 & 13.5 & 6.59 & NA & 4.60 & 13.58 & 2.02 & 4.92 & & 0 & \\
\hline & & & & & & & & & & & & \\
\hline & & & & & & 0.5 & & & & & 27 & \\
\hline & & & & 56 & 20 & 5.98 & 11.93 & A & 42.39 & 4 & 9.26 & 5.50 \\
\hline & 3.50 & & & 58 & 2.40 & 1.33 & 3.53 & 14.25 & & 0.91 & 0.85 & 1.72 \\
\hline & 4.30 & 18.78 & 19.29 & 20.24 & 13.87 & 22.37 & 11.64 & 14.75 & 11.52 & & 18.55 & 24.10 \\
\hline KOR & 1.36 & 9.75 & 3.88 & 6.27 & 3.29 & 3.42 & 11.17 & 7.91 & 4.60 & 4.86 & NA & 6.25 \\
\hline & 0.86 & 3.98 & 4.05 & 5.99 & 3.49 & 3.43 & 10.12 & 1.78 & 13.18 & 3.51 & 2.28 & NA \\
\hline Sum & 74.63 & 61.68 & 58.41 & 55.30 & 54.12 & 51.25 & 73.00 & 47.03 & 82.66 & 41.03 & 41.99 & 52.46 \\
\hline
\end{tabular}

Notes : 1 . 'Org.' and 'Dest.' mean origin country and destination country of trade flows, respectively.

2. The numbers in each cell denote the import share of a country in the first row from the country in the first column.

3. Country names are abbreviated as BRU for Brunei, IND for Indonesia, MAL for Malaysia, PHL for the Philippines, VET for Vietnam, CHI for China, HKC for Hong Kong, JAP for Japan, KOR for Korea and CTP for Taiwan.

Sources : Calculated from the data in IMF (2003), Direction of Trade Statistics, CD-ROM and Taiwan Ministry of Finance (2002), Monthly Statistics of Exports and Imports Taiwan Area September 2002, October. 
(b) Export Share by Destination Country

\begin{tabular}{c|c|c|c|c|c|c|c|c|c|c|c|c|c}
\hline Org.West. & BRU & IND & MAL & PHL & SGP & THL & VET & CHI & HKC & JAP & KOR & CTP & Sum \\
\hline \hline BRU & NA & 0.77 & 0.14 & 0.01 & 4.95 & 10.57 & 0.01 & 3.57 & 0.02 & 47.08 & 12.34 & 0.00 & 79.48 \\
\hline IND & 0.04 & NA & 3.09 & 1.15 & 10.69 & 1.87 & 0.59 & 4.95 & 2.14 & 21.84 & 6.14 & 3.81 & 56.31 \\
\hline MAL & 0.31 & 1.78 & NA & 1.47 & 16.95 & 3.66 & 0.53 & 4.20 & 4.55 & 13.55 & 3.34 & 4.71 & 55.06 \\
\hline PHL & 0.01 & 0.49 & 3.83 & NA & 6.6 & 3.82 & 0.22 & 2.26 & 4.99 & 16.49 & 3.52 & 9.36 & 51.65 \\
\hline SGP & 0.34 & 0.00 & 17.35 & 2.53 & NA & 4.36 & 1.73 & 4.38 & 8.8 & 7.67 & 3.85 & 2.77 & 53.87 \\
\hline THL & 0.06 & 2.10 & 4.18 & 1.78 & 8.12 & NA & 1.22 & 4.40 & 5.07 & 15.30 & 1.89 & 3.35 & 47.46 \\
\hline VET & 0.01 & 2.08 & 2.03 & 1.71 & 5.41 & 2.08 & NA & 7.54 & 1.66 & 17.13 & 2.45 & 2.93 & 45.04 \\
\hline CHI & 0.00 & 0.93 & 0.99 & 0.46 & 1.90 & 0.93 & 0.58 & NA & 18.63 & 14.75 & 3.65 & 1.83 & 44.66 \\
\hline HKC & 0.03 & 0.49 & 0.92 & 1.08 & 2.04 & 0.95 & 0.31 & 37.35 & NA & 5.50 & 1.70 & 1.05 & 51.43 \\
\hline JAP & 0.01 & 1.59 & 2.78 & 2.07 & 3.57 & 2.88 & 0.44 & 7.72 & 5.58 & NA & 6.13 & 6.29 & 39.06 \\
\hline KOR & 0.01 & 2.14 & 1.72 & 1.65 & 2.66 & 1.21 & 1.13 & 11.87 & 6.17 & 10.77 & NA & 4.38 & 43.71 \\
\hline CTP & 0.01 & 1.20 & 2.49 & 1.75 & 3.30 & 1.73 & 1.41 & 3.86 & 21.94 & 10.38 & 2.67 & NA & 50.74 \\
\hline
\end{tabular}

Notes : 1. 'Org.' and 'Dest.' mean origin country and destination country of trade flows, respectively.

2. The numbers in each cell denote the export share of a country in the first column to the country in the first row.

3. Country names are abbreviated as BRU for Brunei, IND for Indonesia, MAL for Malaysia, PHL for the Philippines, VET for Vietnam, CHI for China, HKC for Hong Kong, JAP for Japan, KOR for Korea and CTP for Taiwan.

Sources : Calculated from the data in IMF (2003), Direction of Trade Statistics, CD-ROM and Taiwan Ministry of Finance (2002), Monthly Statistics of Exports and Imports Taiwan Area September 2002, October.

Table 6. Trends of Intra-East Asia Trade Share

(percent)

\begin{tabular}{l||c|c|c|c|c|c}
\hline \multicolumn{1}{c||}{} & \multicolumn{3}{c|}{ Imports } & \multicolumn{3}{c}{ Exports } \\
\cline { 2 - 7 } & 1989 & 1995 & 2001 & 1989 & 1995 & 2001 \\
\hline \hline \multicolumn{1}{c||}{ Brunei } & 61.2 & 67.0 & 74.6 & 94.4 & 95.1 & 79.5 \\
\hline Indonesia & 47.1 & 52.3 & 61.7 & 65.5 & 59.6 & 56.3 \\
\hline Malaysia & 53.4 & 56.8 & 58.4 & 55.1 & 54.3 & 55.1 \\
\hline Philippines & 47.3 & 51.0 & 55.3 & 37.1 & 41.4 & 51.7 \\
\hline Singapore & 50.9 & 57.6 & 54.1 & 43.2 & 53.3 & 53.9 \\
\hline Thailand & 54.3 & 52.9 & 51.3 & 38.9 & 48.2 & 47.5 \\
\hline Vietnam & 9.2 & 74.2 & 73.0 & 20.9 & 63.7 & 45.0 \\
\hline China & 45.2 & 43.9 & 47.0 & 63.0 & 56.4 & 44.7 \\
\hline Hong Kong & 73.4 & 79.4 & 82.7 & 44.3 & 48.9 & 51.4 \\
\hline Japan & 29.3 & 34.9 & 41.0 & 28.6 & 42.6 & 39.1 \\
\hline Korea & 38.1 & 39.6 & 42.0 & 35.7 & 45.0 & 43.7 \\
\hline Taiwan & 43.4 & 48.3 & 52.5 & 34.3 & 51.2 & 50.7 \\
\hline
\end{tabular}

Sources : Calculated from the data in IMF (2003), Direction of Trade Statistics, CD-ROM and Taiwan Ministry of Finance (2002), Monthly Statistics of Exports and Imports Taiwan Area September 2002, October. 


\section{TRADE COMPLEMENTARITY BETWEEN EAST ASIAN COUNTRIES}

\subsection{Index of Trade Conformity}

In the previous part, the analyses were focused on the changes and current structures of international trade between East Asian countries. To make further progress in economic cooperation in East Asia, we should be more familiar and make more efficient use of complementarities between East Asian countries. With the performances and current situation of East Asian trade in mind, we try to analyze complementarity in international trade between these nations. The idea is to measure the extent of structural similarities between each pair of East Asian countries. We hope to denote the trade complementarity using a single measure so that we can compare the measures from the different combinations of East Asian countries. We also hope to measure complementarity differentiated by the direction of trade, that is, the trade complementarity between country $i$ 's exports and country $j$ 's imports and that between country $i$ 's imports and country $j$ 's exports are two different measures. We also hope to identify some commodities that have relatively large contributions to the trade complementarity between each pair of East Asian countries identified by the direction of trade flows. For this purpose, we adopt the index of trade conformity (ITC) discussed in Linnemann and van Beers (1988). The ITC, as one of many trade related indices, seems to be an appropriate measure to analyze the complementarity of international trade between two countries. It tries to measure the extent of overall similarities between a country's export structure by commodity and a trade partner country's import structure by commodity. The export or import structure is measured as the share of each commodity in the aggregate exports or imports of the country in concern.

Formally, the ITC between country $j$ 's exports and country $k$ 's imports is measured with the following formula. ${ }^{3}$

$$
I T C_{j k}=\sum_{i}\left(X_{i j} * M_{i k}\right) / S Q R T\left(\sum_{i} X_{i j}^{2} * \sum_{i} M_{i k}{ }^{2}\right),
$$

where $X_{i j}$ denotes the export share of commodity $i$ in country $j$ 's aggregate exports, Mik denotes the import share of commodity $i$ in country $k$ 's aggregate imports, $\sum_{i}$ denotes the sum of all of the $n$ commodities $i=1,2,3, \ldots, n, S Q R T$ denotes the function of square root.

Some characteristics of the ITC can be summarized as follows. First, the ITC measures structural similarities in international trade by commodity between two countries as a single measure. It can be derived based on the trade performances of as detailed number of commodities as possible. Second, the ITC can have a value from 0 to 1. The more similar a country's export structure to another country's import structure, the closer the ITC is to 1 . Third, the ITC is sensitive to the direction of trade flows between

\footnotetext{
${ }^{3}$ Mathematically the ITC measure is related to the value of $\cos \theta$, where $\theta$ is the smaller angle between the two vectors $X_{i j}$ and $M_{i k}$ in the $n$-dimensional space, where $i=1,2,3, \ldots, n$. In general, the dot product of two vectors $a$ and $b$ is defined by $a \cdot b=|a||b| \cos \theta$, where $\theta$ is the smaller angle between the two vectors.
} 
two countries. More specifically, the ITC, based on the import structure of country $i$ and the export structure of country $j$, is a different measure from that based on the import structure of country $j$ and the export structure of country $i$. Fourth, the ITC measures structural similarities between two countries with the actual trade performances of the two countries by commodity. However, the ITC can be interpreted as being the potential to increase bilateral trade between two countries since it is applied to the aggregate rather than bilateral trade data of the two countries in concern. Fifth, the ITC can also be interpreted as the summation of each commodity's contribution, as implied in the formula. By using these characteristics, commodities that would potentially increase trade between two countries can be identified. In addition, we can rank the commodities by their extent of contributions to the index or denote them with their shares of contribution.

\subsection{Trade Complementarity between East Asian Countries}

Trade complementarity is one of the key elements that would enable East Asian countries to share the benefits of economic growth and development. We try to measure the extent of structural similarity between an East Asian country's exports and another East Asian country's imports with the ITC and SITC three-digit trade data for 6 ASEAN members and 4 Northeast Asian countries. ${ }^{4}$ Each East Asian country's import or export structure is measured using the average shares of SITC three-digit commodities in its aggregate imports or exports for five years from 1997 to 2001. ${ }^{5}$ Relatively high trade complementarity between a country $j$ (export structure) and a country $k$ (import structure), that is, an ITC measure close to 1 , implies that country $j$ 's exports to country $k$ has relatively high potential of increasing with reference to their aggregate import and export structures, respectively.

\subsubsection{Trade Complementarity in Terms of Imports of a Country}

The ITCs between East Asian countries are measured as in Table 7. The average of ITC measures between a country k's imports and each of the remaining 9 East Asian countries' exports can also be examined as an aggregate measure as in the last row. Northeast Asian countries have relatively large average ITC measures between their imports and other East Asian countries' exports. However, in ASEAN members, Indonesia and Brunei have significantly small average ITC measures between their imports and other East Asian countries' exports. By individual country, the average of ITC measures between imports and each of the remaining countries' exports is relatively

4 SITC stands for Standard International Trade Classification by the United Nations. Three-digit classification of SITC Revision 3 includes 261 commodities from 001 (Live Animals except Fish) to 971 (Gold Non-Monetary except Ore). For Brunei, trade data is available only for 1997/1998 from the UN COMTRADE database. Chinese Taipei and Vietnam are not included in the analysis since consistent trade data is not available for them in the UN COMTRADE database.

${ }^{5}$ We need disaggregated trade data for some period of time since trade structure as the share of each commodity in the aggregated trade of an economy may fluctuate year by year. We can get a somewhat stable trade structure by averaging the trade share of each commodity for some years. 
large in Hong Kong (0.606), Singapore (0.593), Japan (0.577), Thailand (0.570), China (0.564) and the Philippines (0.559). However, it is relatively small in Indonesia $(0.240)$ and Brunei (0.289).

By regional subgroup and individual country, most ASEAN members (except Brunei and Indonesia) have relatively large ITC measures between their imports and the exports of other ASEAN countries (again, excluding Brunei and Indonesia) and Korea and Japan of Northeast Asia. Most Northeast Asian countries have relatively large ITC measures between their imports and the exports of other East Asian countries, including both Northeast Asian countries themselves and ASEAN members.

Table 7. ITC Measures between East Asian Countries

\begin{tabular}{l||c|c|c|c|c|c|c|c|c|c|c}
\hline Org. Dest. & BRU & IND & MAL & PHL & SGP & THL & CHI & HKC & JAP & KOR & Ave \\
\hline \hline BRU & NA & 0.034 & 0.047 & 0.285 & 0.162 & 0.320 & 0.214 & 0.031 & 0.628 & 0.494 & 0.281 \\
\hline IND & 0.198 & NA & 0.177 & 0.314 & 0.299 & 0.437 & 0.407 & 0.357 & 0.730 & 0.527 & 0.383 \\
\hline MAL & 0.201 & 0.205 & NA & 0.888 & 0.926 & 0.789 & 0.742 & 0.777 & 0.591 & 0.674 & 0.644 \\
\hline PHL & 0.098 & 0.075 & 0.951 & NA & 0.901 & 0.724 & 0.643 & 0.685 & 0.436 & 0.627 & 0.571 \\
\hline SGP & 0.180 & 0.261 & 0.802 & 0.759 & NA & 0.674 & 0.670 & 0.721 & 0.518 & 0.576 & 0.573 \\
\hline THL & 0.315 & 0.265 & 0.618 & 0.658 & 0.723 & NA & 0.624 & 0.761 & 0.524 & 0.442 & 0.548 \\
\hline CHI & 0.389 & 0.261 & 0.283 & 0.314 & 0.401 & 0.382 & NA & 0.787 & 0.514 & 0.305 & 0.404 \\
\hline HKC & 0.197 & 0.086 & 0.464 & 0.473 & 0.483 & 0.458 & 0.431 & NA & 0.551 & 0.445 & 0.399 \\
\hline JAP & 0.592 & 0.283 & 0.592 & 0.550 & 0.604 & 0.567 & 0.582 & 0.577 & NA & 0.436 & 0.531 \\
\hline KOR & 0.434 & 0.385 & 0.812 & 0.789 & 0.834 & 0.779 & 0.767 & 0.756 & 0.700 & NA & 0.695 \\
\hline Ave & 0.289 & 0.240 & 0.527 & 0.559 & 0.593 & 0.570 & 0.564 & 0.606 & 0.577 & 0.503 & \\
\hline N & & & & & & & & & & \\
\hline
\end{tabular}

Notes : 1 . The numbers in each cell denote the ITC measure between the export structure of a country in the first column and the import structure of a country in the first row. The numbers in the last row and the last column, denoted as 'Ave,' are average ITCs of each row or column, respectively.

2. Country names are abbreviated as BRU for Brunei, IND for Indonesia, MAL for Malaysia, PHL for the Philippines, CHI for China, HKC for Hong Kong, JAP for Japan and KOR for Korea.

\subsubsection{Trade Complementarity in Terms of Exports of a Country}

Average ITC measures can be examined in the other direction, that is, between a country $j$ 's exports and each of the remaining 9 other countries' imports in the last column of Table 7. By regional subgroup, ASEAN members (except Brunei and Indonesia) and Korea and Japan in Northeast Asia have relatively large average ITC measures between their exports and each of the remaining countries' imports. By individual economy, the average ITC measures between a country's exports and each of the remaining countries' imports is relatively large in Korea (0.695), Malaysia (0.644), Singapore (0.573), the Philippines (0.571) and Japan (0.531). However, they are relatively small in Brunei (0.265) and Indonesia (0.383).

By regional subgroup and individual country, most ASEAN members have relatively large ITC measures between their exports and the imports of other countries, including most Northeast Asian countries and Malaysia, the Philippines, Singapore and Thailand of 
the other ASEAN members. In Northeast Asia, both Japan and Korea have relatively large ITC measures between their exports and most of the other countries' imports. China has relatively large ITC measures between its exports and the imports of many other countries, especially Hong Kong and Japan.

\subsubsection{Complementary Commodities}

Since the ITC measure is denoted as a symmetric summation of contributions from each commodity's trade structure, we can identify each commodity's relative contribution to the aggregate index (ITC) and rank the commodities by the extent of their contribution. The top 25 complementary commodities, accounting for about 10 percent of the total 261 SITC three-digit commodities, are identified for each pair of countries' trade in both directions. They are organized as tables in terms of a country's export to each of the remaining 9 other East Asian countries and sorted by their extent of contributions to the ITC. ${ }^{6}$ Consequently, they can be regarded as having potential to increase trade between the two countries.

\section{(1) ASEAN members}

For Brunei, its exports reveal relatively high complementarity with other East Asian countries in SITC 333 (petroleum, bitumen oil, crude), 334 (heavy petroleum, bitumen oils), 343 (natural gas), 764 (telecommunications equipment, nes) and 792 (aircraft, spacecraft, etc.). In addition, its exports have relatively high complementarity in SITC 793 (ships, boats, etc.) with other ASEAN members; SITC 776 (valves, transistors, etc.) and 845 (articles of apparel, nes) with Northeast Asian countries.

Table 8. The top 25 SITC Three-Digit Commodities by their Contribution to the ITC - From the ITC between Brunei Exports and Other Country's Imports

\begin{tabular}{c||c|c|c|c|c|c|c|c|c}
\hline \multirow{2}{*}{ Rank } & IND & MAL & PHL & SGP & THL & CHI & HKC & JAP & KOR \\
\hline \hline 1 & 333 & 333 & 333 & 333 & 333 & 333 & 343 & 333 & 333 \\
\hline 2 & 334 & 334 & 334 & 334 & 343 & 334 & 845 & 343 & 343 \\
\hline 3 & 793 & 792 & 764 & 792 & 792 & 792 & 334 & 334 & 334 \\
\hline 4 & 792 & 764 & 792 & 764 & 334 & 764 & 764 & 845 & 792 \\
\hline 5 & 764 & 793 & 776 & 793 & 764 & 931 & 844 & 792 & 764 \\
\hline 6 & 679 & 931 & 759 & 845 & 931 & 343 & 792 & 764 & 776 \\
\hline 7 & 723 & 776 & 728 & 776 & 776 & 776 & 841 & 931 & 845 \\
\hline 8 & 695 & 874 & 874 & 931 & 695 & 874 & 776 & 844 & 793 \\
\hline 9 & 784 & 781 & 781 & 752 & 793 & 793 & 752 & 841 & 874 \\
\hline 10 & 874 & 695 & 772 & 874 & 699 & 845 & 842 & 781 & 728 \\
\hline
\end{tabular}

\footnotetext{
${ }^{6}$ Only the table for Brunei appears as an example. Tables for the remaining countries can be offered upon request.
} 


\begin{tabular}{c||c|c|c|c|c|c|c|c|c}
\hline Rank & IND & MAL & PHL & SGP & THL & CHI & HKC & JAP & KOR \\
\hline \hline 11 & 744 & 679 & 793 & 844 & 874 & 728 & 781 & 752 & 695 \\
\hline 12 & 728 & 772 & 845 & 759 & 845 & 679 & 931 & 874 & 752 \\
\hline 13 & 782 & 778 & 778 & 695 & 784 & 752 & 759 & 776 & 841 \\
\hline 14 & 749 & 728 & 679 & 723 & 759 & 749 & 874 & 842 & 778 \\
\hline 15 & 713 & 759 & 744 & 679 & 772 & 778 & 69 & 695 & 679 \\
\hline 16 & 781 & 752 & 723 & 778 & 749 & 772 & 778 & 793 & 772 \\
\hline 17 & 699 & 749 & 695 & 772 & 778 & 744 & 843 & 759 & 784 \\
\hline 18 & 778 & 744 & 782 & 728 & 679 & 695 & 772 & 778 & 744 \\
\hline 19 & 712 & 699 & 784 & 781 & 781 & 759 & 771 & 843 & 759 \\
\hline 20 & 343 & 845 & 749 & 841 & 728 & 784 & 699 & 784 & 713 \\
\hline 21 & 772 & 723 & 752 & 744 & 752 & 723 & 716 & 699 & 699 \\
\hline 22 & 752 & 782 & 931 & 699 & 744 & 781 & 744 & 679 & 844 \\
\hline 23 & 742 & 716 & 699 & 749 & 716 & 716 & 749 & 728 & 282 \\
\hline 24 & 743 & 713 & 716 & 716 & 713 & 699 & 728 & 772 & 749 \\
\hline 25 & 716 & 771 & 713 & 898 & 723 & 841 & 793 & 749 & 716 \\
\hline
\end{tabular}

Note : The names of countries are abbreviated as IND for Indonesia, MAL for Malaysia, PHI for the Philippines, SGP for Singapore, THL for Thailand, CHI for China, HKC for Hong Kong, JAP for Japan and KOR for Korea.

For Indonesia, its exports have relatively high complementarity with other East Asian countries in SITC 333 (petroleum, bitumen oil, crude), 334 (heavy petroleum, bitumen oils), 343 (natural gas), 764 (telecommunications equipment, nes), 776 (valves, transistors, etc.) and 752 (computer equipment). In addition, its exports have relatively high complementarity in SITC 759 (office equipment parts, accessories), 931 (special transactions, nes) with other ASEAN members; and SITC 321 (coal, non-agglomerated) with Northeast Asian countries.

For Malaysia, its exports have relatively.high complementarity with other East Asian countries in SITC 776 (valves, transistors, etc.), 752 (computer equipment), 333 (petroleum, bitumen oil, crude), 759 (office equipment parts, accessories), 764 (telecommunications equipment, nes) and 772 (electric circuit equipment).

For the Philippines, its exports have relatively high complementarity with other East Asian countries in SITC 776 (valves, transistors, etc.), 752 (computer equipment), 759 (office equipment parts, accessories), 764 (telecommunications equipment, nes) and 772 (electric circuit equipment). In addition, its exports have relatively high complementarity in SITC 334 (heavy petroleum, bitumen oils) with other ASEAN members; and SITC 845 (articles of apparel, nes) with Northeast Asian countries.

For Singapore, its exports have relatively high complementarity with other East Asian countries in SITC 776 (valves, transistors, etc.), 752 (computer equipment), 334 (heavy petroleum, bitumen oils), 759 (office equipment parts, accessories), 764 (telecommunications equipment, nes), 778 (electrical equipment, nes) and 772 (electric circuit equipment).

For Thailand, its exports have relatively high complementarity with other East Asian countries in SITC 776 (valves, transistors, etc.), 759 (office equipment parts, accessories), 
764 (telecommunications equipment, nes), 752 (computer equipment) and 334 (heavy petroleum, bitumen oils). In addition, its exports have relatively high complementarity in SITC 772 (electric circuit equipment), 042 (rice) with other ASEAN members; and SITC 333 (petroleum, bitumen oil, crude) with Northeast Asian countries.

\section{(2) Northeast Asian Countries}

For China, its exports have relatively high complementarity with other East Asian countries in SITC 776 (valves, transistors, etc.), 752 (computer equipment), 764 (telecommunications equipment, nes), 894 (baby carrier, toy, game, sports) and 333 (petroleum, bitumen oil, crude). In addition, its exports have relatively high complementarity in SITC 759 (office equipment parts, accessories) and 778 (electrical equipment, nes) with ASEAN members; SITC 845 (articles of apparel, nes) and with other Northeast Asian countries.

For Hong Kong, its exports have relatively high complementarity with other East Asian countries in SITC 776 (valves, transistors, etc.), 764 (telecommunications equipment, nes), 845 (articles of apparel, nes) and 759 (office equipment parts, accessories). In addition, its exports have relatively high complementarity in SITC 772 (electric circuit equipment) and 778 (electrical equipment, nes) with ASEAN members; SITC 841 (men's, boys' wear, woven) and 842 (women's, girls' clothing, woven) with Japan and other Northeast Asian countries.

For Japan, its exports have relatively high complementarity with other East Asian countries in SITC 776 (valves, transistors, etc.), 781 (passenger cars, etc.), 752 (computer equipment), 764 (telecommunications equipment, nes), 759 (office equipment parts, accessories) and 778 (electrical equipment, nes). In addition, its exports have relatively high complementarity in SITC 772 (electric circuit equipment) with ASEAN members and other Northeast Asian countries.

For Korea, its exports have relatively high complementarity with other East Asian countries in SITC 776 (valves, transistors, etc.), 781 (passenger cars, etc.), 752 (computer equipment), 764 (telecommunications equipment, nes), 759 (office equipment parts, accessories) and 334 (heavy petroleum, bitumen oils). In addition, its exports have relatively high complementarity in SITC 793 (ships, boats, etc.) with ASEAN members; and SITC 653 (man-made woven fabrics) with other Northeast Asian countries.

\section{POTENTIAL TRADE BETWEEN EAST ASIAN COUNTRIES}

\subsection{The Gravity Model of Trade}

In this part, we try to estimate potential trade between each pair of East Asian countries and compare them with their actual trade performances. For this purpose, we apply the gravity model of trade for 21 APEC member economies, as a reference group, including East Asian countries. The gravity model of trade is to explain aggregated trade flows between two countries by their overall economic activity (GDP) and the distance between the two economies. ${ }^{7}$ It originated from the principle of gravity between two 
masses in physics. The data set for the analysis was obtained from the IMF (2003), the Taiwan Ministry of Finance (2002) for bilateral trade data between APEC member economies in 2001, Jon Haveman's homepage (www.haveman.org) for the physical distance between two capital cities, and the ITC estimates as in the previous part for complementarities in trade among APEC member economies. Since countries are usually much more concerned about measuring and managing their imports than exports, bilateral import data is believed to be more reliable than corresponding export data measured by the trade partner country for the same trade flows. For this reason, we adopted bilateral trade data in 2001 measured in terms of one country's imports rather than exports for each pair of the 21 APEC member economies.

\subsection{Basic Model with Directions of Trade and Potential Trade}

We tried to estimate potential trade considering the directions of trade, i.e., trade from country $j$ to country $k$ and that from country $k$ to country $j$ are entered in the model separately and independently. Now, the basic gravity model is to explain the imports of an APEC member economy from another by utilizing the product of the two countries' GDP and physical distance between them. However, we modified the basic model by deflating both sides by the GDP of the importing country. ${ }^{8}$ Therefore, we try to estimate the potential imports of a country relative to its GDP in reference to the trade partner's GDP and the distance between them. The basic gravity model with directions of trade is applied to 420 pairs of 21 APEC member economies' bilateral trade, GDP and distance data from 2001. The estimated equation is as follows,

$$
\begin{aligned}
\log \left(M_{j k} / G D P_{k}\right)= & 7.014+0.874 * \log \left(G D P_{j}\right)-1.203 * \log \left(D_{j k}\right)-1.705 * D_{\text {rus }} \\
& (0.655)(0.036)
\end{aligned}
$$

$R$-squared: 0.672

Adjusted R-squared: 0.670

F-statistic: 273.804

Prob.(F-statistic): 0.000

Number of observations: $420(=21 * 20)$

Note: The numbers in the parenthesis under each estimated coefficient are standard errors. The variable names $M_{j b} G D P_{j}, G D P_{b} D_{j k}$ denote the imports of the APEC member economy $k$ from the member economy $j$, the GDP of economy $j$, the GDP of economy $k$ in 2001 and the distance between two capital cities of economy $j$ and economy $k$, respectively. In addition, the variable name $D_{n u}$ in the equation denotes the dummy variable having the value of 1 if Russia's bilateral trade is related and 0 otherwise. The Russian dummy $\left(D_{n u}\right)$ is added since it joined APEC in November 1998 and still reveals an exceptionally low level of integration through international trade with other APEC member economies.

\footnotetext{
${ }^{7}$ A good example of applying the gravity model can be found in Chapter 4 of Frenkel, ed. (1998).

${ }^{8}$ This is important since the trade flows of two directions, different from physical gravity between two masses, do not usually balance each other. Even the same amount of trade flows might be recognized differently, especially by the size of the economies in concern. Therefore, we want to explain relative trade deflated by the size of the importing economy.
} 
Overall, intra-East Asian trade is estimated to increase potentially about 175.6 percent. ${ }^{9}$ By regional subgroup, especially trade flows from Northeast Asian countries to Northeast Asian countries are estimated to increase more significantly, about 265.7 percent. However, potential trade flows from East Asia (or from regional subgroups in East Asia) to ASEAN are estimated to be significantly smaller than actual trade flows.

Table 8. Actual and Potential Trade from the Basic Model by Regional Subgroup

(millions of US dollar, percent)

\begin{tabular}{c|c|r|r|r}
\hline \multicolumn{1}{c|}{ Origin } & Destination & $\begin{array}{c}\text { Actual Tade } \\
(\mathbf{A})\end{array}$ & $\begin{array}{c}\text { Potential Trade }^{2} \\
(\mathbf{B})\end{array}$ & $\begin{array}{c}\text { Ratio (\%) } \\
(\mathbf{B} / \mathbf{A} * \mathbf{1 0 0})\end{array}$ \\
\hline \hline \multirow{2}{*}{ E. Asia $^{3}$} & E. Asia & $754,570.5$ & $1,324,806.6$ & 175.6 \\
\cline { 2 - 5 } & ASEAN & $194,385.6$ & $96,747.9$ & 49.8 \\
\cline { 2 - 5 } & NE. Asia & $560,184.9$ & $1,228,058.8$ & 219.2 \\
\hline \multirow{2}{*}{ ASEAN $^{3}$} & E. Asia & $207,196.5$ & $125,891.7$ & 60.8 \\
\cline { 2 - 5 } & ASEAN & $73,608.1$ & $31,279.8$ & 42.5 \\
\cline { 2 - 5 } & NE. Asia & $133,588.4$ & $94,593.9$ & 70.8 \\
\hline \multirow{2}{*}{ NE. Asia $^{3}$} & E. Asia & $507,374.0$ & $1,198,914.9$ & 219.0 \\
\cline { 2 - 5 } & ASEAN & $120,777.5$ & $65,450.1$ & 54.2 \\
\cline { 2 - 5 } & NE. Asia & $426,596.5$ & $1,133,464.8$ & 265.7 \\
\hline
\end{tabular}

Notes : 1 . Actual trade denotes bilateral trade from the country in the first column to the country in the second column. It is measured in terms of each country's imports from the other country in 2001.

2. Potential trade denotes bilateral trade forecast from the basic gravity model and applied for the APEC member economies based on 2001 data.

3. 'E. Asia' includes both ASEAN members and 'NE. Asia.' ASEAN means its seven member countries. 'NE. Asia' denotes China, Hong Kong, Japan, Korea and Taiwan.

Sources : Actual trade data is from IMF. 2003. Direction of Trade Statistics. CD-ROM. March and Taiwan Ministry of Finance. 2002. Monthly Statistics of Exports and Imports Taiwan Area- September 2002. October.

\subsection{Alternative Model with Directions of Trade and Potential Trade}

We tried to estimate potential trade in consideration of the directions of trade. However, we want to consider the structural similarity between the two countries in concern with the index of trade conformity. Since the ITC is differentiated in terms of the directions of trade, it will match relatively well with the gravity model differentiated by the directions of trade. So, the alternative gravity model with directions of trade is to explain the imports of an APEC member economy from another deflated by its GDP with the trading partner country's GDP, the physical distance between them and the structural similarity between the former country's imports and the latter country's exports. It is applied to 342 pairs of 19 out of the 21 APEC member economies' bilateral trade, GDP and distance data from $2001 .^{10}$ The estimated equation is as follows,

\footnotetext{
${ }^{9}$ For the sake of parsimony, the table for actual and potential bilateral trade by each pair of East Asian countries is not included. However, the information, as in Table 4-2, can be offered upon request.

${ }^{10}$ Taiwan and Vietnam are not included since comparable international trade data by commodity is not available in the UN's COMTRADE database.
} 


$$
\begin{aligned}
\log \left(M_{j k} / G D P_{k}\right)= & 7.386+0.774 * \log \left(G D P_{j}\right)-1.300 * \log \left(D_{j k}\right) \\
& (0.798)(0.044) \quad(0.089) \\
& +1.065 * I T C_{j k}-1.509 * D_{n i s} \\
& (0.377) \quad(0.245)
\end{aligned}
$$

R-squared: 0.695

Adjusted R-squared: 0.691

F-statistic: 184.693

Prob.(F-statistic): 0.000

Number of observations: $342(=19 * 18)$

Note: The numbers in the parenthesis under each estimated coefficient are standard errors. The variable names $M_{j b} G D P_{j}, G D P_{b}, D_{j b} I T C_{j k}$ denote the imports of APEC member economy $k$ from member economy $j$, the GDP of economy $j$, the GDP of economy $k$ in 2001, the distance between the two capital cities of economy $j$ and economy $k$ and the ITC measures between economy $j$ 's export structure and economy k's import structure for 1997-2001, respectively. In addition, the variable name $D_{n s}$ in the equation denotes the dummy variable having the value of 1 if Russia's bilateral trade is related and 0 otherwise.

The estimated potential trade (imports) measures from the results are summarized in Table 9. The first column and the second column are a pair of countries where their bilateral trade is originated and destined, respectively. The third column is actual bilateral trade from the country in the first column to the country in the second column in 2001. The fourth column is the potential bilateral trade from the country in the first column to the country in the second column estimated by the model in reference to the available information from APEC members including East Asian countries in 2001. The fifth and last column is the ratio of the potential to actual bilateral trade (imports). So the last column can be interpreted as how many times the bilateral trade of the East Asian countries can potentially increase in consideration of the APEC members' bilateral trade performances, their overall economy performance (GDP) in 2001 and their vicinity. The structure of the table is the same as the previous one.

The potential-actual trade ratio is estimated as significantly large between most Northeast Asian countries, except trade to and from Brunei which has a relatively small actual trade volume, especially from Korea to Japan (1,482.3 percent), from Hong Kong to Japan (1,056.3 percent) and followed by from Korea to China (468.4 percent), from Japan to China (460.3 percent), from Japan to Korea (441.6 percent), China to Japan (386.5 percent), from Hong Kong to Korea (379.8 percent) and from China to Korea (361.5 percent).

The potential-actual trade ratio is estimated as relatively large also among ASEAN members to and from Brunei followed by from the Philippines to China (309.2 percent), from the Philippines to Indonesia (292.7 percent), from China to the Philippines (232.9 percent), from the Philippines to Japan (226.6 percent), from Hong Kong to Thailand (198.4 percent), from Thailand to China (172.5 percent) and from Singapore to Japan (156.6 percent).

In general, the potential-actual trade ratio is estimated with a similar pattern as the model without ITC measures, but actual-potential trade ratios from Korea to other Northeast Asian countries have significantly increased especially to Japan and China. The 
potential-actual trade ratios between Northeast Asian countries are still estimated as some of the highest cases among the pairs of APEC member economies even though the range of the ratios becomes larger than those from the basic model. Overall, the integration between East Asian countries in different regional subgroups (i.e., between ASEAN members and Northeast Asian countries) are more significant by considering complementarities in trade (ITC) compared with the results from the basic gravity model of trade.

Table 9. Actual and Potential Bilateral Trade from the Alternative Model with Directions of Trade

\begin{tabular}{|c|c|c|c|c|}
\hline Origin & Destination & $\begin{array}{l}\text { Actual Tade } \\
\text { (A) }\end{array}$ & $\begin{array}{l}\text { Potential Trade } \\
\text { (B) }\end{array}$ & $\begin{array}{l}\text { Ratio (\%) } \\
(\mathrm{B} / \mathrm{A} * 100) \\
\end{array}$ \\
\hline Indonesia & Singapore & 0.0 & 2112.9 & NA \\
\hline Brunei & Philippines & 0.5 & 80.3 & 16383.2 \\
\hline Brunei & Hong Kong & 0.8 & 66.1 & 8691.6 \\
\hline Korea & Japan & 17633.7 & 261381.7 & 1482.3 \\
\hline Brunei & Malaysia & 5.2 & 61.4 & 1193.2 \\
\hline Hong Kong & Japan & 3290.2 & 34753.6 & 1056.3 \\
\hline Brunei & Indonesia & 16.4 & 156.3 & 952.8 \\
\hline Philippines & Brunei & 5.2 & 34.9 & 668.9 \\
\hline China & Brunei & 17.5 & 91.1 & 519.3 \\
\hline Japan & Brunei & 57.1 & 274.1 & 479.6 \\
\hline Korea & China & 21099.4 & 98833.9 & 468.4 \\
\hline Japan & China & 39364.7 & 181206.6 & 460.3 \\
\hline Japan & Korea & 26633.4 & 117606.5 & 441.6 \\
\hline China & Japan & 58259.2 & 225172.9 & 386.5 \\
\hline Hong Kong & Korea & 1227.6 & 4662.5 & 379.8 \\
\hline China & Korea & 13302.7 & 48108.9 & 361.6 \\
\hline Philippines & China & 1839.9 & 5689.6 & 309.2 \\
\hline Philippines & Indonesia & 136.8 & 400.4 & 292.7 \\
\hline Korea & Brunei & 18.1 & 44.8 & 247.3 \\
\hline Indonesia & Brunei & 25.9 & 60.4 & 233.7 \\
\hline China & Philippines & 917.7 & 2136.9 & 232.9 \\
\hline Philippines & Japan & 6800.5 & 15413.3 & 226.6 \\
\hline Brunei & China & 130.9 & 267.3 & 204.3 \\
\hline Hong Kong & Thailand & 825.0 & 1636.5 & 198.4 \\
\hline Thailand & China & 3905.4 & 6737.5 & 172.5 \\
\hline Singapore & Japan & 6110.6 & 9569.9 & 156.6 \\
\hline Thailand & Japan & 10463.4 & 14428.5 & 137.9 \\
\hline Philippines & Hong Kong & 2025.6 & 2673.6 & 132.0 \\
\hline Philippines & Korea & 1819.0 & 2260.3 & 124.3 \\
\hline Thailand & Korea & 1589.2 & 1742.7 & 109.7 \\
\hline Hong Kong & Philippines & 1641.5 & 1766.6 & 107.6 \\
\hline Indonesia & Japan & 16018.9 & 16282.6 & 101.6 \\
\hline
\end{tabular}

Notes : 1 . Actual trade denotes bilateral trade from the country in the first column to the country in the second column. It is measured in terms of each country's imports from the other country in 2001.

2. Potential trade denotes bilateral trade forecasted from the alternative model applied for the APEC member economies based on 2001 data.

Sources: Actual trade data comes from IMF. 2003. Direction of Trade Statistics. CD-ROM. March and Taiwan Ministry of Finance. 2002. Monthly Statistics of Exports and Imports Taiwan Area-September 2002. October. 
Table 10. Actual and Potential Trade from the Alternative Model by Regional Subgroup

\begin{tabular}{c|c|r|r|r}
\hline \multicolumn{1}{c|}{ Origin } & Destination & $\begin{array}{c}\text { Actual Tade }^{1} \\
(\mathbf{A})\end{array}$ & $\begin{array}{c}\text { Potential Trade }^{2} \\
(\mathbf{B})\end{array}$ & $\begin{array}{c}\text { (millions of US dollar, percent) } \\
\text { Ratio (\%) } \\
\left(\mathbf{B} / \mathbf{A}^{* 100)}\right.\end{array}$ \\
\hline \hline \multirow{2}{*}{ E. Asia $^{3}$} & E. Asia & $618,653.7$ & $1,220,458.5$ & 197.3 \\
\cline { 2 - 5 } & ASEAN & $166,992.1$ & $91,012.7$ & 54.5 \\
\cline { 2 - 5 } & NE. Asia & $449,821.0$ & $1,123,690.2$ & 249.8 \\
\hline \multirow{2}{*}{ ASEAN $^{3}$} & E. Asia & $180,454.4$ & $149,485.4$ & 82.8 \\
\cline { 2 - 5 } & ASEAN & $67,343.6$ & $40,580.8$ & 60.3 \\
\cline { 2 - 5 } & NE. Asia & $113,110.8$ & $108,904.6$ & 96.3 \\
\hline \multirow{2}{*}{ NE. Asia $^{3}$} & E. Asia & $438,199.3$ & $1,070,973.1$ & 244.4 \\
\cline { 2 - 5 } & ASEAN & $99,648.5$ & $50,431.9$ & 50.6 \\
\cline { 2 - 5 } & NE. Asia & $338,550.8$ & $1,020,541.2$ & 301.4 \\
\hline
\end{tabular}

Notes : 1. Actual trade denotes bilateral trade from the country in the first column to the country in the second column. It is measured in terms of each economy's imports from the other economy in 2001.

2. Potential trade denotes bilateral trade forecast from the alternative gravity model applied for the APEC member economies based on 2001 data.

3. 'E. Asia' includes both ASEAN members and 'NE. Asia.' ASEAN means its seven member countries but Vietnam in this table. 'NE. Asia' denotes China, Hong Kong, Japan and Korea in this table.

Source : Actual trade data comes from IMF. 2003. Direction of Trade Statistics. CD-ROM. March.

\subsection{Attaining Trade Potential}

Even with the rapid progress of multilateral trade liberalization, institutionalized regional economic cooperation proliferates, especially in Europe and North America, two out of three major regions in world trade. East Asian countries need more institutionalized cooperative measures based on their complementarity, especially to enhance the economic integration between ASEAN and Northeast Asia. East Asian countries need to identify some practical ways to enhance economic cooperation between each other and to attain trade potential that is estimated to be significantly larger than their current performance.

First, practical and feasible cooperation might be based on their dynamism in world trade, their regional vicinity and their complementarity in the trade of East Asia as a whole. Priority in economic cooperation should be given to the commodities and industrial sectors that reveal relatively strong complementarity between their trade structures. To enhance economic cooperation between East Asian countries and attain trade potential, they need to fully utilize complementary relationships among each other. They should make an effort to enlarge active economic relationships within each regional subgroup and into East Asia as a whole. Priority in economic cooperation should be given to the commodities and industrial sectors that reveal relatively strong complementarity between East Asian countries. For example, complementary relationships in inter-industry trade between ASEAN (natural resources such as petroleum, natural gas, coal and apparel) and Northeast Asian countries (industrial goods such as passenger cars, ships, machinery, man-made fiber fabrics) could be utilized and further developed. Complementary relationships that can also be found in intra-industry trade are in industrial goods such as electric and electronic equipment, especially office equipment, telecommunications equipment, related parts and accessories. 
Second, we need to identify major trade obstacles and priorities to implement some practical cooperative measures. In addition to multilateral trade liberalization, mostly focused on tariff reductions, the main areas of cooperation between East Asian countries might be overall reform in trade related procedures and institutions. Trade facilitation, to reduce trade related costs and time, would be included as one of the most related areas. In the major reports on trade barriers by country, more transparency and consistency related to trade procedures and institutions is often required for most East Asian countries. Some examples are customs procedures, customs valuation and related inspection; quarantine, standards, technical regulations and conformity assessment procedures; domestic distribution related barriers, and so on. "The need to accept global standards and harmonize national domestic rules and regulations with international ones cannot be overemphasized.

\section{SUMMARY AND IMPLICATIONS}

In this paper, we tried to analyze the economic relationships of East Asian countries since the establishment of APEC in 1989, that is, the changes, performance and potential in terms of trade among each of them. The results can be summarized as follows.

First, in terms of international trade, ASEAN members' share in world trade has significantly increased since 1989. Both Northeast Asian countries and ASEAN members have a significantly larger share of world exports than that of world imports, respectively. China experienced significant increases in its share of world trade, while Japan recorded the largest decrease in its share.

Second, East Asian countries' import and export share within East Asia is generally increasing and were at about 53 percent and 47 percent in 2001, respectively. They are much greater than shares in global imports and exports, which were some 22 percent and 25 percent in 2001 , respectively.

Third, regional subgroups in East Asia, ASEAN and Northeast Asian countries, have been integrating faster between countries in each regional subgroup than they have been integrating with East Asian countries as a whole. Therefore, the economic implications of integration within each of the regional subgroups need to be examined so that the trend is consistent, harmonious with, and can ultimately contribute to the integration of East Asia as a whole.

Fourth, most ASEAN members, except Brunei and Indonesia, have relatively large complementarity measures (ITC) between their imports and the exports of other countries, including Korea and Japan of Northeast Asia. Most Northeast Asian countries have relatively large ITC measures between their imports and the exports of other countries, including Northeast Asian countries themselves and ASEAN members. In addition, most ASEAN members have relatively large ITC measures between their exports and the imports of other countries, including most Northeast Asian countries and Malaysia, the

\footnotetext{
" USTR (2003), 2003 National Trade Estimate Report on Foreign Trade Barriers., and European Commission (2004), Market Access Database. [http://europa.eu.int].
} 
Philippines, Singapore and Thailand among other ASEAN members. In Northeast Asia, both Japan and Korea have relatively large ITC measures between their exports and most of the other countries' imports. China has relatively large ITC measures between its exports and the imports of many other countries, especially Hong Kong and Japan.

Fifth, complementary commodities are identified from the degree of their contribution to the ITC between a country's exports and another country's imports. Some examples are as follows. In ASEAN, most members have a relatively high complementarity with other East Asian countries in their exports of SITC 776 (valves, transistors, etc.), 752 (computer equipment), 759 (office equipment parts, accessories), 764 (telecommunications equipment, nes) and 772 (electric circuit equipment). In addition, Brunei and Indonesia have relatively high complementarity with other East Asian countries in their exports of SITC 333 (petroleum, bitumen oil, crude), 334 (heavy petroleum, bitumen oils) and 343 (natural gas). In Northeast Asia, most countries have a relatively high complementarity with other East Asian countries in their exports of SITC 776, 764, 759 and 752. In addition, China has a relatively high complementarity with other East Asian countries in its exports of SITC 894 (baby carrier, toy, game, sports), 333 and 845 (articles of apparel, nes); Hong Kong in its exports of SITC 845, 841 (men's, boys' wear, woven) and 842 (women's, girls' clothing, woven); Japan in its exports of SITC 781 (passenger cars, etc.), 778 (electric equipment, nes) and 784 (motor vehicle parts, accessories); and Korea in its exports of SITC 781, 334, 793 (ships, boats, etc.), 784 and 653 (man-made woven fabric).

Sixth, we estimated potential trade between East Asian countries with the gravity model of trade and compared these with actual bilateral trade performances from 2001 . The integration within Northeast Asia is estimated to have a high potential. Overall, it is estimated to have significant potentiality by regional subgroup, ASEAN or Northeast Asia, and not between the two regional subgroups. However, the potential integration between East Asian countries in different regional subgroups is more significant by considering complementarities in trade compared with results from the basic gravity model.

Finally, to enhance economic cooperation between East Asian countries, they should be able to fully utilize their complementary relationships. They should make an effort to enlarge active economic relationships within each regional subgroup into East Asia as a whole, and this should be based on the complementary relationships between each of them. For example, expanding relationships such as inter-industry trade in natural resources trade and industrial goods between regional subgroups could occur. They should also utilize complementary relationships from intra-industry trade in industrial goods such as electric and electronic equipment, related parts and accessories. Further, they should focus on the implementation of trade facilitation measures based on global standards. 


\section{REFERENCES}

Frenkel, Jeffrey A. ed. 1998. The Regionalization of the World Economy. The University of Chicago Press.

IMF. 2003. Direction of Trade Statistics. CD-ROM. March.

Linnemann, Hans and Cees van Beers. 1988. "Measures of Export-Import Similarity, and the Linder Hypothesis Once Again.” Weltwirtschaftliches Archiv, 124:3.

Nam, Sang-yirl. 2000. "Competition and Complementarity in Northeast Asian Trade: Korea's Perspective.” Working Paper 00-02. KIEP. April.

Nam, Sang-yirl. 2003. Trade Structure and Complementarity among APEC Member Economies. APEC Study Series 03-01. KIEP. December.

Soesastro, Hadi. 1999. “APEC after 10 Years.” Presented in APEC Study Center Consortium 1999 Conference. Auckland, New Zealand. May.

Sohn, Chan-Hyun and Jinna Yoon. 2001. "Does the Gravity Model Fit Korea's Trade Patterns?” Working Paper 01-01. KIEP.

Taiwan Ministry of Finance. 2002. Monthly Statistics of Exports and Imports Taiwan Area-September 2002. October.

United Nations. 2003. International Trade Center Homepage. [www.un.org]

United Nations. 1986. Standard International Trade Classification Revision 3. Statistical Papers Series M, No.34/Rev. 3.

WTO. 2003. World Trade Report 2003. Geneva. 